\title{
The Effect of Distance Education on Self-efficacy towards Online Technologies and Motivation for Online Learning
}

\author{
Gül Özüdoğru ${ }^{* a}$ \\ a(ORCID ID: 0000-0002-5128-1258), Kırşehir Ahi Evran University, Kırşehir, Turkey, gerturk@ahievran.edu.tr \\ *Corresponding author
}

\author{
ARTICLE INFO \\ Received: 2 October 2021 \\ Revised: 3 December 2021 \\ Accepted: 14 December 2021

\section{Keywords:} \\ Distance education \\ Online technologies \\ Motivation, \\ Self-efficacy \\ Psychological counselor candidate
}

doi: 10.53850/joltida. 1003915

\begin{abstract}
This research aimed to investigate the effect of distance education during the COVID-19 pandemic on psychological counselor candidates' self-efficacy perceptions towards online technologies and their motivation for online learning. Single group pretest-posttest model, a quantitative method, was used in the research. The study participants were third-year students at the Faculty of Education, Psychological Counseling and Guidance Department of a state university in the fall semester of 20202021. Demographic Information Form, Online Technologies Self-Efficacy Scale and Online Motivation Scale were used as data collection tools. As a result of the research, it was observed that the psychological counselor candidates' self-efficacy for online technologies and online learning motivation scores were above the average. It was concluded that the distance education used during the COVID-19 pandemic caused a statistically significant difference in psychological counselor candidates' self-efficacy towards online technologies, but did not cause a difference in their online learning motivation. There was no significant difference in self-efficacy according to gender and place of residence. However, while there was no significant difference in motivation according to gender, a significant difference was observed in regards to the place of residence in favor of citycenter. It is important to present psychological counselor candidates' perceptions and motivations in regards to distance education, which is an ongoing process at the moment, for their professional development.
\end{abstract}

\section{INTRODUCTION}

Distance education has been used in education for many years. Distance education allows teachers and students from different places to participate in all or most of the learning and teaching process at differing times by using information and communication technologies for interaction (Moore \& Kearsley, 2012). Distance education, which provides self-learning opportunity, is individualized, adaptable and flexible method compared to face-to-face education (Kaya, 2002). It provides learners with time-space independence, equality of opportunity in education, the right to education for employees, access to large masses, and education based on students' interests and abilities (İşman, 2011). Associate, undergraduate, and graduate programs in most universities utilize distance education or blended learning environments where face-to-face education and distance education are used together (Cabi \& Ersoy, 2017).

Today, there are many terms to describe the implementation of digital technologies in learning, such as distance, online, open, flexible, blended, flipped, hybrid and Massive Open Online Courses (Hartnett, 2016), often used interchangeably, however, there are significant differences in their meanings (Bates, 2016). The root of online learning is based on distance education (Hartnett, 2016).

With the widespread use of distance education, online learning has become significant. Online learning is defined as the transfer of knowledge and skills through electronic technologies and the execution of educational activities through electronic media (Ulutaş, 2016). Online learning environments allow educational practices to be free of physical boundaries of the classroom and studentteacher, student-student interaction takes place as an element of education (Y1ldız, 2020). Çelen et al. (2011) stated that course materials in online learning environments should contain information about the course, transfer competencies, provide students with activities and responsibilities and ensure that students are active. This study examined the effect of the distance education process on two different variables: self-efficacy for online technologies and online learning motivation.

\section{Self-efficacy for online technologies}

Self-efficacy is one of the most important concepts that affect behavior (Bandura, 1971). Alqurashi (2016) stated that individuals' efficacy beliefs may affect their determination to achieve the desired results in a successful manner, adding that rather than regarding difficult tasks as obstacles to be avoided, individuals with high self-efficacy view them challenges that can improve their skills. The perception of self-efficacy, which is related to learning and performance in distance education, is generally associated with achievement, persistence and effort in educational environments (Horzum \& Çakır, 2009). 
Online learning activities require a high level of digital literacy and knowledge and skills to use various digital technologies necessary for interaction and communication in online learning environments (Sun \& Rogers, 2021). Learners should be able to use online technologies comprehensively to participate in online learning, including how to use the internet, sending and receiving emails, participating in online discussions, accessing course materials, and returning homework (Lee, 2015; Wang et al., 2013). Students' self-efficacy beliefs regarding their online learning capacities are an important part of their online learning competencies (Sun \& Rogers, 2021).

Self-efficacy is important for learning environments. Since deficiencies in knowledge and skills will hinder online learning, students' online learning self-efficacy is a critical element in measuring student readiness for online learning (Sun \& Rogers, 2021). Alqurashi (2016) examined the studies on self-efficacy in online learning environments from 1997 to 2015 and emphasized the need for further research on self-efficacy in online learning environments. Peechapol et al. (2018) examined the studies between 2005 and 2017 in their research and reported that the factors affecting self-efficacy in online learning were learning motivation and attitude, online learning experience and knowledge, feedback and reward, communication and interaction, and social impact. Alemayehu and Chen (2021) found that self-efficacy, motivation and self-monitoring were effective on learning engagement in online learning environments. Murphy and Alexander (2000) regarded self-efficacy as one of the important concepts in studies on motivation in relation to academic achievement. Self-efficacy is one of the key aspects of motivation, a factor required in online learning (Zimmerman \& Kollikowichi 2016). Chang et al. (2014) concluded in their research that university students' internet self-efficacy is a factor affecting their motivation.

\section{Online learning motivation}

Motivation is defined as the desire or tendency guiding people to perform a specific behavior. (Özbaş1 et al., 2018). Learning motivation can be defined as a comprehensive incentive for students to perform behaviors and learning activities to achieve desired goals (Apriana \& Hidajat, 2020). Motivation plays a key role in developing and maintaining a sense of community in addition to ensuring learning and achievement in online contexts, (Harnett, 2016). Li and Tsai (2017) found that students' behavior is related to their motivation in online learning environments.

The design of the learning environment is also an important issue for motivation in online learning environments. Understanding students' motivation and what they expect to gain from a course affect the design of the program of that course (Bates, 2016). The ARCS (Attention, Relevance, Confidence, and Satisfaction) Model, which takes its foundation from the expectation value theory, is a method for developing instructional materials from a motivational point of view by emphasizing the importance of motivation on learning (Keller, 1987). Such instructional design approaches are crucial in developing an understanding of motivation in online learning environments (Hartnett, 2016).

Undoubtedly, psychological counseling services of institutions play an important role in the successful execution of distance education processes. In order to support the continuity of learners and to ensure that educational goals are achieved, guidance and psychological counseling services should improve their practices during the course process, post-lesson and evaluation processes (Özer, 2020). It was found that the students had various difficulties in regards to learning and experienced stress, loneliness, anxiety, etc. in the distance education they were given during the COVID-19 pandemic (Apriyanti, 2020; Muslimin \& Harintama, 2020). Psychological counseling and guidance service practises developed by identifying the needs and expectations of learners in distance education processes are important to provide functional services suitable to meet individual differences (Özer, 2020). In this case, school psychological counselors have a great role to play. In addition, online psychological counseling has become widespread as a result of the demands of today's learners to use technology for the purpose of receiving psychological support (Zeren, 2017).

In their studies, Tuzgöl Dost and Keklik (2012) and Parmaksız and Gök (2018) found that one of the reasons for the difficulties encountered by the school counselors in their profession was insufficient practice opportunities during their undergraduate education. For this reason, it is important for psychological counselors to have sufficient experiences in their undergraduate training. It will be beneficial to train psychological counselors during pre-service training with experience in distance education and competence and motivation in online technologies since they will have to use these technologies in their professional lives upon graduation. The distance education processes consist of online courses as well as online psychological counseling services. Hence, psychological counselor candidates' self-efficacy and online learning motivation for the technologies they need to communicate with their students during the distance education processes become significant.

This research aimed to investigate the effect of distance education used during the COVID-19 pandemic on psychological counselor candidates' self-efficacy perceptions towards online technologies and their online learning motivation. The research problem is as follows: "Does the distance education utilized during the COVID-19 pandemic have an effect on psychological counselor candidates' self-efficacy perceptions towards online technologies and their motivation for online learning?". The sub-problems of the study are listed below;

1. Does distance education have an effect on psychological counselor candidates' self-efficacy for online technologies?

2. Does psychological counselor candidates' self-efficacy for online technologies differ according to gender?

3. Does psychological counselor candidates' self-efficacy for online technologies differ according to place of residence?

4. Does distance education have an effect on psychological counselor candidates' online learning motivation?

5. Does psychological counselor candidates' online learning motivation differ according to gender?

6. Does psychological counselor candidates' online learning motivation differ according to place of residence? 


\section{METHOD}

\section{Research model}

The research utilized a single group pretest-posttest design, which is one of the quantitative methods. This is - an ideal method to examine the change in a specific group over a period of time when it would be difficult to find a control group (Creswell, 2012). It was not possible to form a control group because the university solely used distance education at the time of the research. Psychological counselor candidates completed their courses, exams and homework in a distance education environment. The courses were taught asynchronously through the university's learning management system and synchronously through a simultaneous conference system integrated into it. In addition to the weekly live lessons, the lecture notes were uploaded to the system every week by the lecturers.

\section{Participants}

The participants of the research were the third-year students in the Department of Psychological Counseling and Guidance, at a faculty of education in a state university. Table 1 presents the distribution of students based on their demographic data.

Table 1. Distribution of participants by demographic data

\begin{tabular}{lll}
\hline Gender & $\mathbf{N}$ & $\mathbf{\%}$ \\
\hline Female & 40 & 63.5 \\
\hline Male & 23 & 36.5 \\
\hline Total & 63 & 100 \\
\hline Device used for online education & $\mathbf{N}$ & $\mathbf{\%}$ \\
\hline Smartphone & 35 & 55.6 \\
\hline Computer & 28 & 44.4 \\
\hline Total & 63 & 100 \\
\hline Average duration for device use & $\mathbf{N}$ & $\mathbf{\%}$ \\
\hline Less than 1 hour & 1 & 1.6 \\
\hline 1-3 hours & 9 & 14.3 \\
\hline 3-5 hours & 24 & 38.1 \\
\hline 5-7 hours & 18 & 28.6 \\
\hline More than 7 hours & 11 & 17.5 \\
\hline Total & 63 & 100 \\
\hline Average duration for Internet use & $\mathbf{N}$ & $\mathbf{\%}$ \\
\hline Less than 1 hour & 2 & 3.2 \\
\hline 1-3 hours & 25 & 39.7 \\
\hline 3-5 hours & 20 & 31.7 \\
\hline 5-7 hours & 12 & 19.0 \\
\hline More than 7 hours & 4 & 6.3 \\
\hline Total & 63 & 100 \\
\hline Place of residence & $\mathbf{N}$ & $\mathbf{\%}$ \\
\hline Village & 12 & 19.0 \\
\hline District & 18 & 28.6 \\
\hline City center & 33 & 52.4 \\
\hline Total & 63 & 100 \\
\hline
\end{tabular}

Table 1 shows that the majority of the participants were female and the device mostly used during distance education was smartphone. While participants' average daily device usage time for distance education was 3-5 hours at the most, their internet usage time was 1-3 hours at the most. According to the place of residence, the majority of them resided in the citycenter.

\section{Data collection tools}

Demographic Information Form, Online Technologies Self-Efficacy Scale and Online Motivation Scale were used to collect data.

Demographic Information Form: The form that contains information about the gender of the participants, the devices they used for the lessons, the frequency of daily device and internet use for the lessons and their place of residence during the distance education process.

Online Technologies Self-Efficacy Scale (OTSES): The 29-item, 5-point Likert type scale was developed by Miltiadou and Yu (2000) and adapted into Turkish by Horzum and Çakır (2009). The validity and reliability studies of the scale were carried out with university students. As a result of reliability analysis, exploratory and confirmatory factor analysis, it was concluded that the scale is valid and reliable with four dimensions: internet competencies ( 9 items, reliability: 0.89 ), synchronous interaction (4 items, 
reliability: 0.85), asynchronous interaction I (9 items, reliability: 0.90) and asynchronous interaction II (7 items, reliability: 0.89). The overall reliability of the scale is 0.94 .

Online Learning Motivation Scale (OLMS): The 28-item, 7-point Likert type scale was developed by Chen and Jang (2010) and adapted into Turkish by Özbaşı et al. (2018). The validity and reliability studies were carried out with university students. As a result of reliability analysis, exploratory and confirmatory factor analysis, it was concluded that the scale is valid and reliable with seven dimensions: intrinsic motivation to know (4 items, reliability: 0.80), intrinsic motivation to achieve (4 items, reliability: 0.90), intrinsic motivation to experience stimulation (4 items, reliability: 0.81 ), identified regulation (4 items, reliability: 0.84$)$, introjected regulation (4 items, reliability: 0.83), external regulation (4 items, reliability: 0.60), amotivation (4 items, reliability: 0.78). The overall reliability of the scale is 0.94 . In the scale, 4 items are reverse. The lowest and the highest points can be obtained from the scale are 28 and 196, respectively.

\section{Data collection}

Data were collected from students on a voluntary basis in the fall semester of the 2020-2021 academic year. Ethics committee approval was received for this study from the Social and Human Sciences Scientific Research and Publication Ethics Committee of Kurşehir Ahi Evran University, with the decision dated 16.10.2020 and numbered 2020/4. Posttest data were collected 12 weeks after the pretest data collection on a voluntary basis. Figure 1 shows the data collection process.

\section{Data collection/pretest}

\section{Distance education process}

\section{Data collection/posttest}

\section{Figure 1. Data Collection Process}

\section{Data analysis}

The kurtosis and skewness values were examined for the normality distributions of the data. The lowest value is $-1,498$ and the highest is 0.968 . These values are in the range of $+1.5,-1.5$ indicates that the data show a normal distribution (Tabachnick $\&$ Fidell, 2013). Dependent samples t-test, independent samples t-test and ANOVA analysis were performed in the analysis of the data.

\section{FINDINGS}

\section{Findings regarding online technologies self-efficacy}

Dependent samples t-test was used to examine whether psychological counselor candidates' OTSES scores changed at the end of the distance education provided during the COVID-19 pandemic. Pretest-posttest dependent sample t-test results of for the OTSES are as in Table 2.

Table 2. Dependent samples t-test results for OTSES pretest-posttest scores

\begin{tabular}{|c|c|c|c|c|c|c|c|}
\hline OTSES & Test & $\mathbf{N}$ & $\bar{X}$ & $\mathbf{S}$ & Sd & $\mathbf{t}$ & $\mathbf{p}$ \\
\hline \multirow[t]{2}{*}{ Internet Competencies } & Pretest & 63 & 4.17 & 0.63 & \multirow[t]{2}{*}{62} & \multirow[t]{2}{*}{-.557} & \multirow[t]{2}{*}{.579} \\
\hline & Posttest & 63 & 4.22 & 0.42 & & & \\
\hline \multirow{2}{*}{$\begin{array}{l}\text { Synchronous } \\
\text { Interaction }\end{array}$} & Pretest & 63 & 4.10 & 0.67 & \multirow[t]{2}{*}{62} & \multirow[t]{2}{*}{.000} & \multirow[t]{2}{*}{1.000} \\
\hline & Posttest & 63 & 4.10 & 0.51 & & & \\
\hline \multirow[t]{2}{*}{ Asynchronous Interaction I } & Pretest & 63 & 4.07 & 0.62 & \multirow[t]{2}{*}{62} & \multirow[t]{2}{*}{-2.165} & \multirow[t]{2}{*}{$.034 *$} \\
\hline & Posttest & 63 & 4.26 & 0.43 & & & \\
\hline \multirow[t]{2}{*}{ Asynchronous Interaction II } & Pretest & 63 & 3.73 & 0.74 & \multirow[t]{2}{*}{62} & \multirow[t]{2}{*}{-3.338} & \multirow[t]{2}{*}{$.001 *$} \\
\hline & Posttest & 63 & 4.07 & 0.54 & & & \\
\hline \multirow[t]{2}{*}{ General } & Pretest & 63 & 4.01 & 0.57 & \multirow[t]{2}{*}{62} & \multirow[t]{2}{*}{-2.321} & \multirow[t]{2}{*}{$.024 *$} \\
\hline & Posttest & 63 & 4.18 & 0.36 & & & \\
\hline
\end{tabular}

$* \mathrm{p}<.05$

Table 2 shows that the distance education provided during the COVID-19 pandemic caused a statistically significant difference in the psychological counselor candidates' online technologies self-efficacy perceptions $(\mathrm{p}<0.5)$. While the mean OTSES score was 4.01 before distance education, it increased to 4.18 afterwards. The psychological counselor candidates' OTSES scores were above the average. When the sub-dimensions are examined, there are significant differences between the pretest and posttest in favor of the posttest in the dimensions of Asynchronous Interaction I and Asynchronous Interaction II. But, there was no significant 111 
difference between the pretest and posttest dimensions of Internet compenticies and Synchronus interaction ( $p>.05)$. Table 3 shows whether the psychological counselor candidates' OTSES scores differed according to gender.

Table 3. Independent samples t-test results of OTSES scores by gender

\begin{tabular}{lllllll}
\hline Gender & $\mathbf{N}$ & $\overline{\boldsymbol{X}}$ & $\mathbf{S}$ & $\mathbf{S d}$ & $\mathbf{t}$ & $\mathbf{p}$ \\
\hline Female & 40 & 4.19 & 0.40 & 61 & 0.372 & .711 \\
Male & 23 & 4.16 & 0.30 & & & \\
\hline
\end{tabular}

Table 3 shows no difference in the psychological counselor candidates' OTSES scores by gender ( $\mathrm{p}>.05$ ). The mean score of female participants was found to be higher than that of male participants, but this difference was not statistically significant. One-way ANOVA analysis was conducted to examine whether the psychological counselor candidates' OTSES scores differed according to their place of residence. Analysis results are provided in Table 4.

Table 4. ANOVA results of OTSES scores by place of residence

\begin{tabular}{lllllll}
\hline Place of residence & $\mathbf{N}$ & $\overline{\boldsymbol{X}}$ & $\mathbf{s d}$ & $\mathbf{d f}$ & $\mathbf{F}$ & $\mathbf{2}$ \\
\hline Village & 12 & 4.00 & 0.21 & 62 & & \\
District & 18 & 4.19 & 0.44 & & \\
Citycenter & 33 & 4.24 & 0.34 & & \\
\hline
\end{tabular}

According to Table 4, psychological counselor candidates' OTSES scores did not differ significantly according to their place of residence. While those living in the citycenter had the highest mean score and those living in the village had the lowest mean score, this difference was not statistically significant.

\section{Findings regarding online learning motivation}

Dependent samples t-test was used to examine whether psychological counselor candidates' OLMS scores changed at the end of the distance education provided during the COVID-19 pandemic. Pretest-posttest dependent sample t-test results of for the OLMS are as in Table 5.

Table 5. Dependent samples t-test results for OLMS pretest-posttest scores

\begin{tabular}{|c|c|c|c|c|c|c|c|}
\hline OLMS & Test & $\mathbf{N}$ & $\bar{X}$ & $\mathbf{S}$ & Sd & $\mathbf{t}$ & $\mathbf{p}$ \\
\hline \multirow[t]{2}{*}{ Intrinsic motivation to know } & Pretest & 63 & 18.73 & 6.78 & 62 & 0.686 & .496 \\
\hline & Posttest & 63 & 17.95 & 6.43 & & & \\
\hline \multirow[t]{2}{*}{ Intrinsic motivation to accomplish } & Pretest & 63 & 15.70 & 5.73 & 62 & 0.193 & .847 \\
\hline & Posttest & 63 & 15.52 & 5.27 & & & \\
\hline \multirow[t]{2}{*}{ Intrinsic motivation to experience stimulation } & Pretest & 63 & 17.63 & 6.05 & 62 & 0.576 & .567 \\
\hline & Posttest & 63 & 17.11 & 5.25 & & & \\
\hline \multirow[t]{2}{*}{ Identified regulation } & Pretest & 63 & 18.54 & 6.74 & 62 & 1.700 & .094 \\
\hline & Posttest & 63 & 16.68 & 5.47 & & & \\
\hline \multirow[t]{2}{*}{ Introjected regulation } & Pretest & 63 & 14.79 & 6.16 & 62 & -0.988 & .327 \\
\hline & Posttest & 63 & 15.79 & 5.24 & & & \\
\hline \multirow[t]{2}{*}{ External regulation } & Pretest & 63 & 17.16 & 6.09 & 62 & 0.058 & .954 \\
\hline & Posttest & 63 & 17.10 & 5.62 & & & \\
\hline \multirow[t]{2}{*}{ Amotivation } & Pretest & 63 & 18.37 & 4.43 & 62 & 0.644 & .522 \\
\hline & Posttest & 63 & 17.79 & 5.73 & & & \\
\hline \multirow[t]{2}{*}{ General } & Pretest & 63 & 120.92 & 34.78 & 62 & 0.381 & .705 \\
\hline & Posttest & 63 & 118.70 & 31.41 & & & \\
\hline
\end{tabular}

Based on Table 5, the distance education provided during the COVID-19 pandemic did not cause a statistically significant difference in psychological counselor candidates' OLMS ( $>0.5$ ). While the mean OLMS score was 120.92 before the distance education practice, it was found to be 118.7 after the process. Psychological counselor candidates' OLMS general scores were above the average. Table 6 shows whether psychological counselor candidates' OLMS scores differed according to gender.

Table 6. Independent samples t-test results of OLMS scores by gender

\begin{tabular}{lllllll}
\hline Gender & $\mathbf{N}$ & $\overline{\boldsymbol{X}}$ & $\mathbf{S}$ & $\mathbf{S d}$ & $\mathbf{t}$ & $\mathbf{p}$ \\
\hline Female & 40 & 115.68 & 30.34 & 61 & -1.008 & .318 \\
Male & 23 & 123.96 & 33.22 & & & \\
\hline
\end{tabular}

Table 6 points to no difference in psychological counselor candidates' OLMS scores by gender ( $\mathrm{p}>.05$ ). The mean score of males was higher than that of females, but this difference was not statistically significant. One-way ANOVA analysis was conducted to 
examine whether psychological counselor candidates' OLMS scores differed according to their place of residence. Analysis results are provided in Table 7.

Table 7. ANOVA results for OLMS scores by place of residence

\begin{tabular}{llclllll}
\hline Place of Residence & $\mathbf{N}$ & $\overline{\boldsymbol{X}}$ & $\mathbf{s d}$ & $\mathbf{d f}$ & $\mathbf{F}$ & $\mathbf{p}$ & Significant Difference \\
\hline Village & 12 & 100.25 & 37.82 & 62 & 3.922 & $.025^{*}$ & \\
District & 18 & 114.50 & 34.78 & & & & Citycenter $>$ Village \\
Citycenter & 33 & 127.70 & 23.59 & & & & \\
\hline
\end{tabular}

$* \mathrm{p}<.05$

According to Table 7, psychological counselor candidates' OLMS scores differed significantly according to their place of residence $(\mathrm{p}<.05)$. Examination of this difference by Tukey, one of the Post Hoc tests, showed that the difference was in favor of the citycenter.

\section{CONCLUSION AND DISCUSSION}

The results of the research demonstrated that psychological counselor candidates' online technologies self-efficacy perceptions were above the average. OTSES scores significantly increased after the distance education provided during the COVID-19 pandemic. This increase may be due to the extensive use of online technologies in this process by the participants, that is, their improved experience. It was concluded that psychological counselor candidates' OTSES did not differ by gender or place of residence. Chang et al. (2014) reported that males have higher Internet self-efficacy than females while females have higher online discussion participation and final exam scores compared to males. In their research, Yıldız and Seferoğlu (2020) found that distance education university students have high self-efficacy perceptions towards online technologies. In addition,they concluded that males have higher self-efficacy perceptions for online technologies than females. In their research, Öztürk and Kert (2017) examined the effect of an online learning environment on adults' self-efficacy for online technologies. They concluded that while there was a significant difference in some areas according to the courses they attended, there was no difference in others. In a study conducted with university students for a period of time, Lee (2015) reached the conclusion that students' self-efficacy towards online technologies increased.

This study also found that psychological counselor candidates' online learning motivation scores were above average. However, no significant difference was observed in participants' OLMS scores after the distance education provided during the COVID-19 pandemic. There was a significant difference in participants' online motivation in regards to their place of residence, between those residing in the citycenter and the village. This result may be due to the fact that the residents of the village were more likely to experience technical and internet connection problems, causing the village residents to have lower motivation for online learning.

There are studies in the literature reporting that distance education has a positive or negative effect on motivation. In this study, no significant difference was observed in psychological counselor candidates' online learning motivation by gender. However, Chang et al. (2014) concluded that learning motivation in online learning environments was higher in males compared to females. Muslimin and Harintama (2020) concluded that students experienced motivation problems during the COVID-19 pandemic. The study conducted by Hebebci et al. (2020) reported that middle and high school students experienced a loss of motivation in distance education provided during the COVID-19 pandemic. In their study with high school students, Apriana and Hidajat (2020) concluded that the use of Google Classroom in teaching mathematics topics increased online learning motivation. In their research conducted with university students, Susilawati and Supriyatno (2020) reported that the use of WhatsApp during and after COVID-19 pandemic increased students' motivation to learn. Cai and Zhu (2012) stated that the online learning community project had a positive effect on university students' motivation to learn foreign languages.

The COVID-19 pandemic still continues in the world. Distance education, which is mostly used as an option in education, has become a requirement in this process. Governments have embraced online learning during the pandemic to prevent the spread of COVID-19 (Apriana \& Hidajat, 2020). It can be argued that counseling services, which include psychological counseling and guidance, are important to support the permanence of distance learners in the system (Özer, 2020). While distance education is provided during the COVID-19 pandemic, psychological counseling services are provided online in many institutions. This research is significant in showing the importance of pre-service training of the psychological counselors employed at institutions that play a major role in the ongoing fight against the COVID-19 pandemic.

Various experimental studies can be conducted to increase psychological counselors' self-efficacy and motivation for the technologies they will use in this process. The present research only addressed motivation and efficacy variables and further studies can be conducted on different variables. In addition, further studies can be conducted with qualitative approaches, to examine this process in more depth.

Ethics Committee Approval: Ethics committee approval was received for this study from the Social and Human Sciences Scientific Research and Publication Ethics Committee of Kirşehir Ahi Evran University, with the decision dated 16.10.2020 and numbered 2020/4. 


\section{REFERENCES}

Alemayehu, L., \& Chen, H. L. (2021). The influence of motivation on learning engagement: the mediating role of learning selfefficacy and self-monitoring in online learning environments. Interactive Learning Environments, 1-14. https://doi.org/10.1080/10494820.2021.1977962

Alqurashi, E. (2016). Self-efficacy in online learning environments: A literature review. Contemporary Issues in Education Research, 9(1), 45-52. https://doi.org/10.19030/cier.v9i1.9549

Apriana, A., \& Hidajat, D. (2020). Analysis of Google Classroom's online learning motivation on mathematics subjects. Journal of Mathematical Pedagogy (JoMP), 2(1), 18-25. https://doi.org/10.26740/jomp.v2n1.p\%25p

Apriyanti, C. (2020). Distance learning and obstacles during Covid-19 outbreak. Jurnal Ilmiah Pendidikan Dasar, 7(2), 68-83. http://dx.doi.org/10.30659/pendas.7.2.68-83

Bandura, A. (1971). Psychological modeling: Conflicting theories. Chicago: Aldine-Atherton.

Bates, A. W. T. (2018). Teaching in a digital age: Guidelines for designing teaching and learning. Tony Bates Associates Ltd, Vancouver BC.

Cabı, E., \& Ersoy, H. (2017). Analysis of distance education practices in higher education: The example of Turkey. Journal of Higher Education and Science, 7(3), 419-429. Doi: 10.5961/jhes.2017.219

Cai, S., \& Zhu, W. (2012). The impact of an online learning community project on university Chinese as a foreign language students' motivation. Foreign Language Annals, 45(3), 307-329. https://doi.org/10.1111/j.1944-9720.2012.01204.x

Chang, C. S., Liu, E, Z.-F., Sung, H. Y., Lin, C. H., Chen, N. H., \& Cheng, S. S. (2014). Effects of online college student's Internet self-efficacy on learning motivation and performance. Innovations in Education and Teaching International, 51(4), 366-377, Doi: 10.1080/14703297.2013.771429

Chen, K., \& Jang, S. (2010). Motivation in online learning: Testing a model of self-determination theory. Computers in Human Behavior, 26(4), 741-752. https://doi.org/10.1016/j.chb.2010.01.011

Creswell, J. W. (2012). Educational research: Planning, conducting, and evaluating quantitative and qualitative research. Boston, MA: Pearson Education.

Çelen, F. K., Çelik, A., \& Seferoglu, S. S. (2018). Yükseköğretimde çevrim-içi öğrenme: Sistemde yaşanan sorunlar ve çözüm önerileri. Journal of European Education, 1(1), 25-34.

Hartnett, M. (2016). The importance of motivation in online learning. In Motivation in online education (pp. 5-32). Springer, Singapore.

Hebebci, M. T., Bertiz, Y., \& Alan, S. (2020). Investigation of views of students and teachers on distance education practices during the Coronavirus (COVID-19) Pandemic. International Journal of Technology in Education and Science (IJTES), 4(4), 267-282. https://doi.org/10.46328/ijtes.v4i4.113

Horzum, M. B., \& Çakır, Ö. (2009). The validity and reliability study of the Turkish version of the online technologies selfeficacy scale. Educational Sciences: Theory \& Practice, 9(3), 1327-1356.

İşman, A. (2011). Uzaktan eğitim [Distance education]. Ankara: Pegem.

Kaya, Z. (2002). Uzaktan eğitim [Distance education]. Ankara: Pegem.

Keller, J. M. (1987). Development and use of the ARCS model of instructional design. Journal of Instructional Development, $10(3), 2-10$.

Lee, C.-Y. (2015). Changes in self-efficacy and task value in online learning. Distance Education, 36(1), 59-79, Doi: $10.1080 / 01587919.2015 .1019967$

Li, L. Y., \& Tsai, C. C. (2017). Accessing online learning material: Quantitative behavior patterns and their effects on motivation and learning performance. Computers \& Education, 114, 286-297. http://dx.doi.org/10.1016/j.compedu.2017.07.007

Miltiadou, M., \& Yu, C. H. (2000). Validation of the Online Technologies Self-Efficacy Scale (OTSES). AECT International Convention, Denver CO.

Moore, M., \& Kearsley, G. (2012). Distance education: A system view of online learning. Belmont, CA: Wadsworth Cengage Learning.

Murphy, P. K., \& Alexander, P. A. (2000). A motivated exploration of motivation terminology. Contemporary Educational Psychology, 25(1), 3-53. https://doi.org/10.1006/ceps.1999.1019

Muslimin, A. I., \& Harintama, F. (2020). Online learning during pandemic: Students' motivation, challenges, and alternatives. Loquen: English Studies Journal, 13(2), 60-68. Doi: http://dx.doi.org/10.32678/loquen.v13i02

Özbaşı, D., Cevahir, H., \& Özdemir, M. (2018). Adaptation of online learning motivation scale into Turkish: Validity and reliability. Trakya University Journal of Education Faculty, 8(2), 352-368. Doi: 10.24315/trkefd.331973

Özer, N. (2020). Açık ve uzaktan öğrenme sistemlerindeki psikolojik danışmanlık ve rehberlik hizmetlerinin bireysel farklılıklar kapsamında incelenmesi. Açıöğretim Uygulamaları ve Araştırmaları Dergisi, 6(4), 55-80.

Öztürk, P., \& Kert, S. B. (2017). Bir çevrimiçi öğrenme ortamının, yetişkinlerin çevrimiçi öz-yeterlik algıSı ve akademik başarılarına etkisi. Acta Infologica, 1(1), 39-54.

Parmaksız, İ., \& Gök, A. (2018). The difficulties of school counselors in implementation of counseling and guidance services. Mehmet Akif Ersoy University Journal of Education Faculty, 47, 247-265. https://doi.org/10.21764/maeuefd.359595

Peechapol, C., Na-Songkhla, J., Sujiva, S., \& Luangsodsai, A. (2018). An exploration of factors influencing self-efficacy in online learning: A systematic review. International Journal of Emerging Technologies in Learning, 13(9), 64-86. https://doi.org/10.3991/ijet.v13i09.8351

Sun, Y., \& Rogers, R. (2021). Development and validation of the Online Learning Self-efficacy Scale (OLSS): A structural equation modeling approach. American Journal of Distance Education, 35(3), 184-199. https://doi.org/10.1080/08923647.2020.1831357 
Susilawati, S., \& Supriyatno, T. (2020). Online learning through WhatsApp group in improving learning motivation in the era and post pandemic COVID-19. Jurnal Pendidikan: Teori, Penelitian, dan Pengembangan, 5(6), 852-859.

Tabachnick, B. G. \& Fidell, L. S. (2013). Using multivariate statistics. Pearson, Boston.

Tuzgöl Dost, M., \& Keklik, İ. (2012). Professional issues in counseling as perceived by individuals working in counseling settings. Mehmet Akif Ersoy University Journal of Education Faculty, 23, 389-407

Ulutaş, A. (2016). Examination of attitudes of preschool teacher candidates towards reading habit in terms of onlıne learning. Journal of TLCE (Turkish, Literature, Culture, Education), 5(2), 936-948. http://dx.doi.org/10.7884/teke.562

Wang, C. H., Shannon, D. M., \& Ross, M. E. (2013). Students' characteristics, self-regulated learning, technology self-efficacy, and course outcomes in online learning. Distance Education, (34)3, 302-323. Doi: 10.1080/01587919.2013.835779

Widjaja, A. E., \& Chen, J. V. (2017). Online learners' motivation in online learning: The effect of online-participation, social presence, and collaboration. Learning Technologies in Education: Issues and Trends, December, 72-93.

Y1ld1z, E. (2020). Investigation of factors affecting the sense of community of distance education learners in online learning environments. Journal of Qualitative Research in Education, 8(1), 180-205. doi:10.14689/issn.2148-2624.1.8c.1s.9m

Yıldız, E., \& Seferoğlu, S. S. (2020). Examination of self-efficacy perception of distance education students about online technologies. Celal Bayar University Journal of Social Sciences, 18(1), 33-46. https://doi.org/10.18026/cbayarsos.514904

Zeren, Ş. G. (2017). Therapeutic alliance in face-to-face and online counseling: Opinions of counselor candidates. Journal of Human Sciences, 14(3), 2293-2307. doi:10.14687/jhs.v14i3.4203

Zimmerman, W. A., \& Kulikowich, J. M. (2016). Online learning self-efficacy in students with and without online learning experience. American Journal of Distance Education, 30(3), 180-191. Doi: 10.1080/08923647.2016.1193801 